\title{
Monitoring Heavy Metal Contamination in the Pineapple (Ananas comosus) Cultivated tracts of Kerala, India
}

\author{
Samitha K. A. ${ }^{1}$, Rajathy Sivalingam ${ }^{2}$, Sandeep S. ${ }^{3}$, Syamkumar $\mathbf{R}^{4}$ \\ ${ }^{1,2,4}$ School of Environmental Studies, Cochin University of Science and Technology, Cochin \\ ${ }^{3}$ Department of soil Science, Kerala Forest Research Institute, Thrissur
}

\begin{abstract}
Agriculture plays an important role in the sustainable development of the country. Use of chemical fertilizers escalate certain components in excess quantity thereby deteriorate the productivity and leads to unpredicted outcome. This study makes an effort to reckon the accumulation of some selected heavy metals [Lead $(\mathrm{Pb})$, Nickel (Ni) and Cadmium(Cd)] and related indices [bio concentration factor(BCF) and translocation factor (TF)] from roots, leaves and fruits of pineapple plantations in Ernakulam district. Contamination factor(CF), enrichment factor(EF) and geo accumulation index (Igeo) disclose the extent of soil contamination in the pineapple cultivated regions of Ernakulam district. Root to shoot $\mathrm{TF}$ derived for $\mathrm{Pb}, \mathrm{Ni}$, and $\mathrm{Cd}$ were 0.25 , 0.733 and 0.6731 . TF of $\mathrm{Pb}, \mathrm{Ni}$ and $\mathrm{Cd}$ from root to fruit was $0,0.5$ and 0.195 respectively. Values obtained for $\mathrm{BCF}$ of $\mathrm{Pb}, \mathrm{Ni}$ and $\mathrm{Cd}$ in root of the pineapple plant were $0.2013,0.5758$ and 0.3288. In pineapple leaves BCF showed the values $0.0503,0.4222$ and 0.2214 by $\mathrm{Pb}, \mathrm{Ni}$ and $\mathrm{Cd}$. Pineapple fruit showed $\mathrm{BCF}$ values Zero, 0.2879 and 0.0641 for $\mathrm{Pb}$, $\mathrm{Ni}$ and $\mathrm{Cd}$. Enrichment factor for $\mathrm{Pb}$, $\mathrm{Ni}$ and $\mathrm{Cd}$ in pineapple cultivated areas comes under the value 4.2, 3.7 and 2.8 respectively. Furthermore, the contamination factor of $\mathrm{Pb}$, $\mathrm{Ni}$ and $\mathrm{Cd}$ was 9.93, 8.26 and 6.23, respectively. The values of geo accumulation index obtained for different heavy metals pass on that the degree of pollution with respect to $\mathrm{Pb}$ (6.621) was very strong and extremely contaminated, heavily to extremely contaminated for $\mathrm{Ni}(5.513)$ and $\mathrm{Cd}$ (4.15).
\end{abstract}

KEYWORDS: Translocation factor, Bio concentration factor, Contamination factor, Enrichment factor and Geo accumulation index.

\section{INTRODUCTION}

Geochemical monitoring is required to find out credible enrichment due to anthropogenic activities. Farmers use a lot of fertilizers knowingly or unknowingly to get more yields. These chemicals stay in the soil for a long time in quantities greater than the required amount by plants. Heavy metals that accumulate in storage tissues of plants, is passed on to the food chain expedite inauspicious health effect to human beings, further reduce the production and quality of crops [1]. Lead can be found in petrol additives, batteries, mineral industries, paper and wood products, animal and vegetable products, lead based paints, lead solder in plumbing or lead pipes. $\mathrm{Cd}$ is a byproduct of smelting of Zinc, lead and copper moreover $\mathrm{Cd}$ is present in fertilizer and also used as additives in processing PVC resins, color pigments [2]. Cd is toxic to living organism and leads to kidney damage, skeletal damage and cardiovascular diseases. Chief source of heavy metal pollution in agricultural areas are phosphatic fertilizers which have been applied for more than 50 years and keep accumulating in plant tissues [3]. Lead poisoning resulted in headache, abdominal pain, and irritability. It can lead to learning disturbances and diminished intellectual capacity in children due to the mutagenic, teratogenic and carcinogenic properties [4]. Soil contamination of $\mathrm{Cd}$ in agriculture is of global importance because it is accumulated in the edible parts of the plant and often exceed food safety standards [5]. Translocation of heavy metals from roots to aerial parts of the plant revealed phytoextraction which is a mechanism of phytoremediation [6]. Numerous plants eg: Jatropha curcas [7] have the ability for phytoremediation. Bio concentration factor depicts the ability of the plant to accumulate elements from the substrate and translocation factor give out a clear understanding represents for the phytoremediation purpose. Potency of anthropogenic pollutants such as heavy metals on the surface of the soil were estimated by the indexes such as Enrichment Factor (EF) and Geo accumulation index (Igeo). Elements lacking degradation and vertical mobility were chosen as reference element ( $\mathrm{Al}, \mathrm{Fe}, \mathrm{Mn}$ and $\mathrm{Rb}$ ) [8-10] to normalize the metal concentration by examined environment to that of reference element. Pineapple is a fruit of ever growing demand from domestic together with tourism point of view. Large fertilizer input is indispensible for a large scale pineapple production. Nutrient status do provide an useful insight into the impact of agricultural management practices in pineapple 


\section{International Journal of Current Science Research and Review}

ISSN: 2581-8341

Volume 04 Issue 05 May 2021

DOI: 10.47191/ijesrr/V4-i5-14, Impact Factor: 5.825

IJCSRR@ 2021

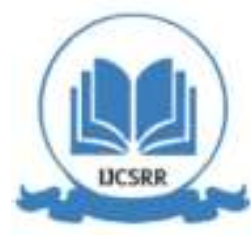

www.ijcsrr.org

cultivation. Haphazed use of chemical fertilizers will increase soil acidity as well as changes in chemical properties consequently affect the soil health. Soil management do need careful consideration to heavy metal for the optimum pineapple growth and for future soil productivity. The study aimed to assess the degree of heavy metal contamination by different indices such as Contamination factor, Enrichment factor and Geo accumulation index.

\section{METHODOLOGY}

Pineapple cultivated areas from different agro ecological regions of Ernakulam district $\left(09^{\circ} 47^{\prime} 13^{\prime}\right.$ ' and $10^{\circ} 10$ ' $44^{\prime}$ 'North latitudes and $76^{\circ} 10^{\prime} 05^{\prime}$ and $77^{\circ} 05^{\prime} 24^{\prime}$ East) were selected for the study. Being plantation area, all sites were exposed to different types of chemical fertilizers and biocides. Soil samples were collected from pineapple cultivated fields of Ernakulam district and the samples were air dried, sieved $(2 \mathrm{~mm})$ and digested with aqua regia (3:1 concentration of hydrochloric acid : nitric acid) for analysis heavy metals $(\mathrm{Pb}, \mathrm{Ni}$ and $\mathrm{Cd})$ and also for Iron $(\mathrm{Fe})$. After extraction metals were estimated by Atomic Absorption Spectrophotometer (AAS). Plant parts such as roots, leaves and fruits were also collected from the same field. Roots, leaves and fruits of the Pineapple plants were separated, washed, dried at $60^{\circ} \mathrm{C}$ in an oven, ground into fine powder and the samples were digested with aqua regia. Heavy metals such as $\mathrm{Pb}, \mathrm{Ni}$ and $\mathrm{Cd}$ were analyzed using AAS.

Translocation factor specify the capacity of the plant to transfer the metals from its roots to shoots and other aerial parts. Translocation factor was calculated by the formula

$$
T F=C_{\text {aerial parts }} / C_{\text {root }}
$$

Where $C_{\text {aerial parts }}$ is the concentration of metal in leaves /fruits and $C_{\text {root }}$ is the concentration of metal in the root. Here estimated TF from Pineapple roots to pineapple leaves and also from Pineapple root to Pineapple fruit. Bio concentration factor can be measured from each plant parts such as root, leaf, fruit etc and was calculated by the formula

$$
B C F=C_{\text {harvested tissue }} / C_{\text {soil }} \text {. }
$$

Where $C_{\text {harvested tissue }}$ is the metal concentration in the plant parts (root//leaf and fruit), $C_{\text {soil }}$ is the concentration of same metal in the soil [11].

Contamination factor was measured accordingly

$$
C_{f}^{i}=C_{0-1}^{i} / C_{n}^{i}
$$

where $C_{0-1}^{i}$ is the mean concentration of metals from examined sites, and $C_{n}^{i}{ }_{i}$ s the concentration of metals from background or baseline area. Contamination was assessed by contamination factor (table 1).

Enrichment factor was determined by the following formula,

$$
E F_{X}=\left[X_{s} / E_{s(r e f)}\right] /\left[X_{c} / E_{c(r e f)}\right]
$$

where $X s$ is the amount of examined metal in the examined environment, $E s_{(r e f)}$ is the amount of examined element in the reference environment, $X c$ is the reference element in the examined environment, $E c_{(\text {ref })}$ is the content of reference element in the reference environment[12].To study Enrichment Factor, Iron ( $\mathrm{Fe}$ ) is used as the reference element. Five contamination categories are conceded on the basis of enrichment factor (table 2).

Degree of contamination was calculated by geo accumulation index (Igeo).

$$
\operatorname{Igeo}=\ln (\mathrm{Cn} / 1.5 * \mathrm{Bn})
$$

where $C n$ is the measured concentration of metal in the cultivated soil, 1.5 is the ground matrix correction factor, $B n$ is the back ground value of heavy metal [13]. The geoaccumulation index and the degree of pollution were shown in the table (table 2).

Table 1: Contamination index of heavy metals

\begin{tabular}{ll} 
Value & Contamination \\
\hline $\mathrm{C}_{\mathrm{f}}^{\mathrm{i}}<1$ & low contamination \\
$1 \leq \mathrm{C}_{\mathrm{f}}{ }^{\mathrm{i}}<3$ & Moderate contamination \\
$3 \leq \mathrm{C}_{\mathrm{f}}{ }^{\mathrm{i}}<6$ & Considerable contamination \\
$6 \leq \mathrm{C}_{\mathrm{f}}^{\mathrm{i}}$ & Very high contamination*
\end{tabular}

Ref: [14] 


\section{International Journal of Current Science Research and Review}

ISSN: 2581-8341

Volume 04 Issue 05 May 2021

DOI: 10.47191/ijesrr/V4-i5-14, Impact Factor: 5.825

IJCSRR@ 2021

www.ijcsrr.org

Table 2: Indices of Enrichment factor and of Geo accumulation

\begin{tabular}{|c|c|c|}
\hline \multirow{6}{*}{ 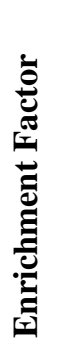 } & Value & soil quality \\
\hline & $\mathrm{EF}<2$ & minimal enrichment \\
\hline & $2<\mathrm{EF}<5$ & moderate enrichment $*$ \\
\hline & $5<\mathrm{EF}<20$ & significant enrichment \\
\hline & $20<\mathrm{EF}<40$ & very high enrichment \\
\hline & $\mathrm{EF}>40$ & Extremely enrichment \\
\hline \multirow{5}{*}{ 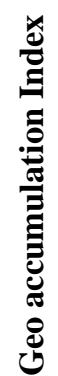 } & Igeo $\leq 0$ & Uncontaminated \\
\hline & $0<$ Igeo $<2$ & moderately contaminated \\
\hline & $2<$ Igeo $<4$ & Heavily contaminated \\
\hline & $4<$ Igeo $<5$ & Heavily to extremely contaminated $*$ \\
\hline & Igeo $\geq 5$ & Extremely contaminated $*$ \\
\hline
\end{tabular}

Ref: [15]

\section{RESULTS AND DISCUSSION}

Average concentration of heavy metals $(\mathrm{Pb}, \mathrm{Ni}$ and $\mathrm{Cd}$ ) in the pineapple cultivated fields are summarized in the (table 3$)$. Mean concentration of $\mathrm{Pb}$ in the pineapple cultivated soil and reference soil ,was found to be $39.73 \mathrm{mgkg}^{-1}$ and $4 \mathrm{mgkg}^{-1}$. Average $\mathrm{Pb}$ content in pineapple cultivated soil is lower than the mean concentration of $\mathrm{Pb}\left(49.71 \mathrm{mgkg}^{-1}\right)$ in soil reported by earlier studies[16].Pineapple root and leaves showed $8 \mathrm{mgkg}^{-1}$ and $2 \mathrm{mgkg}^{-1}$ of Pb. Lead concentration in fruit was found to be below detectable limit (BDL). Nickel showed $10.42 \mathrm{mgkg}^{-1}$ in cultivated soil and $1.26 \mathrm{mgkg}^{-1}$ in reference soil. $6 \mathrm{mgkg}^{-1}, 4.4 \mathrm{mgkg}^{-1}$ and 3 $\mathrm{mg} \mathrm{kg}^{-1}$ were the mean concentration of $\mathrm{Ni}$ in roots, leaves and fruits, respectively. Pineapple cultivated soils showed Cd at a mean concentration of $62.33 \mathrm{mgkg}^{-1}$ and $10 \mathrm{mgkg}^{-1}$ for reference soil. Mean concentration of $20.5 \mathrm{mgkg}^{-1}, 13.8 \mathrm{mgkg}^{-1}, 4 \mathrm{mgkg}^{-1} \mathrm{of} \mathrm{Cd} \mathrm{was}$ present in roots, leaves,fruits respectively. Mean concentration of $25168 \mathrm{mgkg}^{-1} \mathrm{of} \mathrm{Fe}$ was found in the cultivated soil and mean concetration of $11356 \mathrm{mg} \mathrm{kg}^{-1}$ in reference soil. Average concentration of Fe in pineapple root, leaf and fruit was found to be 204 $m g g^{-1}, 184.97 \mathrm{mgk}^{-1}, 145.6 \mathrm{mgkg}^{1}$ respectively.

Table 3: Average concentration $\mathrm{Pb}, \mathrm{Ni}, \mathrm{Cd}$ and $\mathrm{Fe}$ in studied samples

\begin{tabular}{|c|c|c|c|c|c|}
\hline Element & $\begin{array}{l}\text { Average } \\
\text { concentration } \\
\text { cultivatedsoil } \\
\left(\mathrm{mgkg}^{-1}\right)\end{array}$ & $\begin{array}{l}\text { Average } \\
\text { concentration } \\
\text { referencesoil } \\
\left(\mathrm{mgkg}^{-1}\right)\end{array}$ & $\begin{array}{l}\text { Average } \\
\text { concentration } \\
\text { roots }\left(m g k g^{-1}\right)\end{array}$ & $\begin{array}{l}\text { Average } \\
\text { concentration } \\
\text { leaves }\left(m g k g^{-1}\right)\end{array}$ & $\begin{array}{l}\text { Average } \\
\text { concentration } \\
\text { fruits }\left(m g g^{-1}\right)\end{array}$ \\
\hline $\mathrm{Pb}$ & 39.73 & 4 & 8 & 2 & BDL \\
\hline $\mathrm{Ni}$ & 10.42 & 1.26 & 6 & 4.4 & 3 \\
\hline $\mathrm{Cd}$ & 62.33 & 10 & 20.5 & 13.8 & 4 \\
\hline $\mathrm{Fe}$ & 25168 & 11356 & 204 & 184.97 & 145.6 \\
\hline
\end{tabular}

Inorganic chemical fertilisers are the sources of toxic heavy metals such as $\mathrm{Cd}, \mathrm{Pb}$ and $\mathrm{Ni}$ in the agricultural fields[17].Coherence of phytoextraction was quantified by estimating Translocation factor and Bio concentration factor. 


\section{International Journal of Current Science Research and Review}

ISSN: 2581-8341

Volume 04 Issue 05 May 2021

DOI: 10.47191/ijcsrr/V4-i5-14, Impact Factor: 5.825

IJCSRR@ 2021

WwW.ijcsrr.org

\section{Translocation factor of heavy metals}

Value of TF of $\mathrm{Pb}, \mathrm{Ni}$ and $\mathrm{Cd}$ from root to leaf was $0.25,0.733$ and 0.6731 , among metals TF was higher in Ni and metals in decreasing order of $\mathrm{Ni}>\mathrm{Cd}>\mathrm{Pb}$ ( fig 1). Nevertheless, TF of $\mathrm{Pb}, \mathrm{Ni}$ and $\mathrm{Cd}$ from root to fruit was 0, 0.5 and 0.1951, respectively. A TF value (>1) stipulate higher absorption of metal from soil and better suitable for phytoremediation, whereas TF value $<1$ indicate poor absorption and higher edibility. The $\mathrm{TF}$ for $\mathrm{Pb}$ in leaf was 0.25 , while it was not traceable in fruits at detectable limit. TF for $\mathrm{Ni}$ in leaf and fruit was 0.733 and 0.5. Whereas Cd having the TF value 0.673 in leaf and 0.195 in pineapple fruit. From the studied heavy metals $\mathrm{TF}$ was found to be high for $\mathrm{Ni}$ and metals in decreasing order of $\mathrm{TF}$ was $\mathrm{Ni}>\mathrm{Cd}>\mathrm{Pb}$ in both leaf and fruit. Mean concentration of Ni in soil (49.59 $\left.\mathrm{mgkg}^{-1}\right)$ in comparison with background concentration of $\left(16.67 \mathrm{mgkg}^{-1}\right)$ was found in artificially contaminated soils of Mumbai, in which vegetables such as Spinach, Fenugreek and Red Amaranth showed higher affinity towards $\mathrm{Ni}$ and were readily absorbed by the vegetables[18]. Similar results were spot by [19] by considering on Ni contaminated soil.

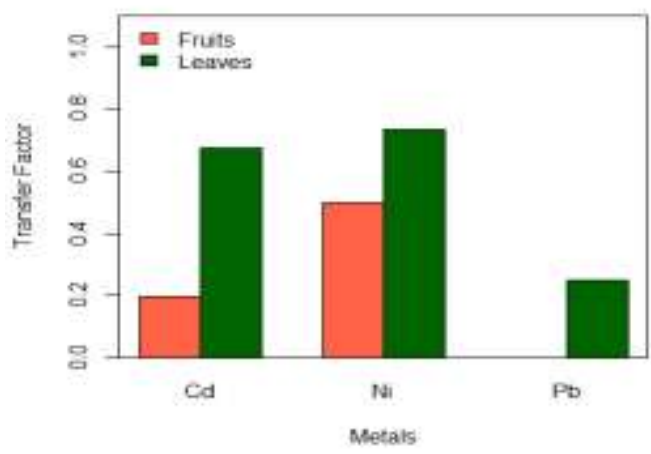

Figure 1: Transfer Factor of heavy metals in leaves and fruits of Pineapple

\section{Bio concentration factor of heavy metals}

Bio concentration of heavy metals in roots, leaves and fruits of the pineapple plant were summarized in the (table 4). $\mathrm{BCF}$ of $\mathrm{Pb}$ in root, leaf and fruit was found to be $0.2013,0.0503$ and 0 , respectively. Root, leaf and fruit of pineapple plant showed BCF of 0.5758 , 0.4222 and 0.2879 for Nickel. For Cd BCF was $0.3288,0.2214$ and 0.0641 in root, leaf and fruit. Order of decreasing value of BCF in root and leaf were $\mathrm{Ni}>\mathrm{Cd}>\mathrm{Pb}$. Nickel showed high $\mathrm{BCF}$ in fruit than $\mathrm{Cd}$. Zero value for $\mathrm{Pb}$ in fruit indicate that $\mathrm{Pb}$ is not translocate to pineapple fruit but other studies reported high amount of $\mathrm{Pb}$ accumulated in various plants [20]. Value of $\mathrm{BCF}>1$ denotes the plant has the capacity to accumulate metal where as $\mathrm{BCF} \leq 1$ indicates that the plants does not have the capacity to accumulate metals.

Table 4: Bio concentration factor of heavy metals in root, leaf and fruit

\begin{tabular}{lclc}
\hline Metal & BOC in root & BOC in leaf & BOC in fruit \\
\hline $\mathrm{Pb}$ & 0.201 & 0.05 & 0 \\
$\mathrm{Ni}$ & 0.575 & 0.422 & 0.287 \\
$\mathrm{Cd}$ & 0.328 & 0.221 & 0.064 \\
\hline
\end{tabular}

\section{Contamination factor, Enrichment factor and Geo accumulation Index of heavy metals}

The contamination factor of $\mathrm{Pb}, \mathrm{Ni}$ and $\mathrm{Cd}$ is 9.93, 8.26 and 6.23 respectively (Fig 2).The order of contamination of heavy metals in the increasing order in pineapple cultivated soils in Ernakulam district was $\mathrm{Cd}<\mathrm{Ni}<\mathrm{Pb}$. Contamination factor for studied heavy metals were high in the pineapple fields and was found to be $>6$ which suggests very high contamination (table 3 ). Overall toxicity status of heavy metals $(\mathrm{Pb}, \mathrm{Ni}$ and $\mathrm{Cd})$ contamination were higher in the coastal areas of Cochin[21]. Similar results were observed in the agricultural soils of Zhejiang Province, China with a contamination factor for $\mathrm{Pb}(9.87)$. Seasonal variation also occurs for heavy metal concentration and it was higher in winter as compared to summer [22]. Banana field soils of Southern India especially Kerala, Karnataka and Tamil Nadu were accommodating boatload of heavy metals by the manifold use of chemical fertilizers [23]. 


\section{International Journal of Current Science Research and Review}

ISSN: 2581-8341

Volume 04 Issue 05 May 2021

DOI: 10.47191/ijcsrr/V4-i5-14, Impact Factor: 5.825

IJCSRR@ 2021

WwW.ijcsrr.org

Enrichment factor of heavy metals were measured by using Fe as reference element because it has no synergism or antagonism towards an examined environment. Values of $\mathrm{EF}<1.5$ indicates that the heavy metals arise from natural weathering process and $\mathrm{EF}>1.5$ denotes pollution or contamination of that area (Table 2). Enrichment factor for $\mathrm{Pb}, \mathrm{Ni}$ and $\mathrm{Cd}$ in pineapple cultivated areas was 4.2, 3.7 and 2.8 respectively (fig 2). All of the value comes under moderately enrichment category. Enrichment factor was high for $\mathrm{Pb}$ followed by $\mathrm{Ni}$ and then by $\mathrm{Cd} . \mathrm{Pb}$ was the most hazardous contaminant present in the pineapple cultivated area.

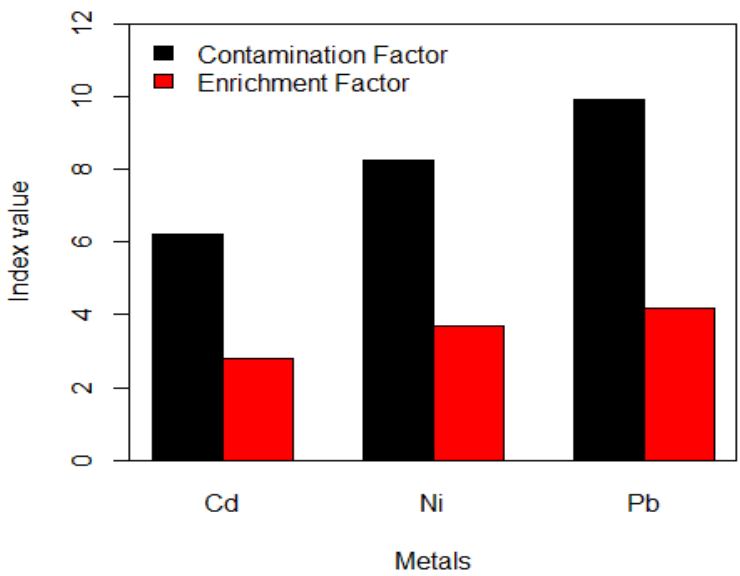

Figure 2: Contamination factor and Enrichment factor of heavy metals

Geo accumulation index (Table 2) varying from Igeo $\leq 0$, unpolluted or uncontaminated and Igeo $>5$ represents extremely contaminated area and this suggests at least a 100-fold enrichment factor above background values [15].The values of geo accumulation index obtained for different heavy metals categorizes the degree of pollution with respect to $\mathrm{Pb}(6.621)$ as 'extremely contaminated', $\mathrm{Ni}(5.513)$ and $\mathrm{Cd}$ (4.15)as 'heavily to extremely contaminated'. Depending on the values of geo accumulation index, it is inferred that the extent of pollution was high for $\mathrm{Pb}$ followed by $\mathrm{Ni}$ and $\mathrm{Cd}$ in pineapple cultivated fields of Ernakulam district. Igeo values of $\mathrm{Cd}$ ranges from 0.29 to 7.4 in estuarine sediments from the east coast of India including Cochin [24]. Igeo values of surface soil near Nansi Lake in China showed higher ecological risk due to Cd than other heavy metals [25].

\section{CONCLUSION}

Although farming is a gift, there is no doubt that indiscriminate farming practices can ruin the fertility and health of the soil. Among the heavy metals studied TF was higher in $\mathrm{Ni}$ and metals are in the decreasing order of $\mathrm{Ni}>\mathrm{Cd}>\mathrm{Pb}$. Bio concentration factor in root and leaf was in the decreasing order of $\mathrm{Ni}>\mathrm{Cd}>\mathrm{Pb}$. Contamination factor of heavy metals are in the increasing order $\mathrm{Cd}<\mathrm{Ni}<\mathrm{Pb}$ in pineapple cultivated soils in Ernakulam district. Enrichment factor for $\mathrm{Pb}, \mathrm{Ni}$ and $\mathrm{Cd}$ was in the increasing order of $\mathrm{Cd}<\mathrm{Ni}<\mathrm{Pb}$. Geo accumulation index rely upon that the extent of heavy metal pollution and was high for $\mathrm{Pb}$ and followed by $\mathrm{Ni}$ and $\mathrm{Cd}$ in the pineapple cultivated areas. The present study reveals substantial evidence to show that the pineapple cultivated areas in Ernakulam district is contaminated by toxic heavy metals, which can result in toxicity to humans and other animals through food chain magnification. The study also stresses the importance of scientific management of cultivation practices in this area by the authorities. The present study represents a preliminary assessment and further studies are warranted to elucidate the underlying causes regarding heavy metal contamination in pineapple cultivated area in and around Ernakulam district.

\section{ACKNOWLEDGEMENT}

Author grateful to Cochin University of Science and Technology for financial support and the department of soil science, Kerala Forest Research Institute for the research facilities. 


\section{International Journal of Current Science Research and Review}

ISSN: 2581-8341

Volume 04 Issue 05 May 2021

DOI: 10.47191/ijesrr/V4-i5-14, Impact Factor: 5.825

IJCSRR @ 2021

WWW.ijcsrr.org

\section{REFERENCE}

1. Rezaei, M., Ghasemidehkordi, B., Peykarestan, B., Shariatifar, N., Jafari, M., Fakhri, Y., Jabbari, M\&Khaneghah, A. M. (2019). Potentially toxic element concentration in fruits collected from Markazi Province (Iran): a probabilistic health risk assessment. Biomedical and environmental sciences, 32(11), 839-853.

2. Dinis, M. D. L., \&Fiuza, A. (2011). Exposure assessment to heavy metals in the environment: measures to eliminate or reduce the exposure to critical receptors. In Environmental heavy metal pollution and effects on child mental development (pp. 27-50). Springer, Dordrecht.

3. Alam, M. G. M., Snow, E. T., \& Tanaka, A. (2003). Arsenic and heavy metal contamination of vegetables grown in Samta village, Bangladesh. Science of the total environment, 308(1-3), 83-96.

4. Järup, L. (2003). Hazards of heavy metal contamination. British medical bulletin, 68(1), 167-182.

5. Xin, J., Huang, B., \& Dai, H. (2015). Difference in root-to-shoot Cd translocation and characterization of Cd accumulation during fruit development in two Capsicum annuum cultivars. Plant and soil, 394(1), 287-300.

6. Padmavathiamma, P. K., \& Li, L. Y. (2007). Phytoremediation technology: hyper-accumulation metals in plants. Water, Air, and Soil Pollution, 184(1), 105-126.

7. Jamil, S., Abhilash, P. C., Singh, N., \& Sharma, P. N. (2009). Jatropha curcas: a potential crop for phytoremediation of coal fly ash. Journal of hazardous materials, 172(1), 269-275.

8. Sutherland, R. A. (2000). Bed sediment-associated trace metals in an urban stream, Oahu, Hawaii. Environmental geology, 39(6), 611-627.

9. Balls, P. W., Hull, S., Miller, B. S., Pirie, J. M., \& Proctor, W. (1997). Trace metal in Scottish estuarine and coastal sediments. Marine pollution bulletin, 34(1), 42-50.

10. Ryan, J. D., \& Windom, H. L. (1988). A geochemical and statistical approach for assessing metal pollution in coastal sediments. In Metals in coastal environments of Latin America (pp. 47-58). Springer, Berlin, Heidelberg.

11. Zhuang, X., Chen, J., Shim, H., \& Bai, Z. (2007). New advances in plant growth-promoting rhizobacteria for bioremediation. Environment international, 33(3), 406-413.

12. Loska, K., Wiechula, D., Barska, B., Cebula, E., \&Chojnecka, A. (2003). Assessment of arsenic enrichment of cultivated soils in Southern Poland. Polish Journal of Environmental Studies, 12(2), 187-192.

13. Förstner, U., Ahlf, W., \&Calmano, W. (1993). Sediment quality objectives and criteria development in Germany. Water Science and technology, 28(8-9), 307-316.

14. Hakanson, L. (1980). An ecological risk index for aquatic pollution control. A sedimentological approach. Water research, 14(8), 975-1001.

15. Barbieri, M. (2016). The importance of enrichment factor (EF) and geoaccumulation index (Igeo) to evaluate the soil contamination. J GeolGeophys, 5(1), 1-4.

16. Ahmad, J. U., \&Goni, M. A. (2010). Heavy metal contamination in water, soil, and vegetables of the industrial areas in Dhaka, Bangladesh. Environmental monitoring and assessment, 166(1), 347-357.

17. Bora, F. D., Bunea, C. I., Rusu, T., \& Pop, N. (2015). Vertical distribution and analysis of micro-, macroelements and heavy metals in the system soil-grapevine-wine in vineyard from North-West Romania. Chemistry Central Journal, 9(1), $1-13$.

18. Rangnekar, S. S., Sahu, S. K., Pandit, G. G., \& Gaikwad, V. B. (2013). Accumulation and translocation of nickel and cobalt in nutritionally important Indian vegetables grown in artificially contaminated soil of Mumbai, India. Research Journal of Agriculture and Forestry Sciences ISSN, 2320, 6063

19. Duman, F., \& Ozturk, F. (2010). Nickel accumulation and its effect on biomass, protein content and antioxidative enzymes in roots and leaves of watercress (Nasturtium officinale R. Br.). Journal of Environmental Sciences, 22(4), 526-532.

20. Sakizadeh, M., Mirzaei, R., \&Ghorbani, H. (2016). Accumulation and soil-to-plant transfer factor of lead and manganese in some plant species in Semnan province, central Iran. Iranian Journal of Toxicology, 10(3), 29-33.

21. Suresh, G., Ramasamy, V., Sundarrajan, M., \&Paramasivam, K. (2015). Spatial and vertical distributions of heavy metals and their potential toxicity levels in various beach sediments from high-background-radiation area, Kerala, India. Marine pollution bulletin, 91(1), 389-400. 


\section{International Journal of Current Science Research and Review}

ISSN: 2581-8341

Volume 04 Issue 05 May 2021

DOI: 10.47191/ijesrr/V4-i5-14, Impact Factor: 5.825

IJCSRR@ 2021

www.ijcsrr.org

22. Hashmi, M. Z., Yu, C., Shen, H., Duan, D., Shen, C., Lou, L., \& Chen, Y. (2013). Risk assessment of heavy metals pollution in agricultural soils of siling reservoir watershed in Zhejiang province, China. BioMed research international, 2013.

23. Sahodaran, N. K., \& Ray, J. G. (2018). Heavy metal contamination in "chemicalized'green revolution banana fields in southern India. Environmental science and pollution research, 25(27), 26874-26886.

24. Chakraborty, Parthasarathi, Darwin Ramteke, Sucharita Chakraborty, and B. NagenderNath. "Changes in metal contamination levels in estuarine sediments around India-an assessment." Marine pollution bulletin 78, no. 1-2 (2014): $15-25$.

25. Guo, H., Yang, L., Han, X., Dai, J., Pang, X., Ren, M., \& Zhang, W. (2019). Distribution characteristics of heavy metals in surface soils from the western area of Nansi Lake, China. Environmental monitoring and assessment, $191(5), 262$.

Cite this Article: Samitha K. A., Rajathy Sivalingam, Sandeep S., Syamkumar R (2021). Monitoring Heavy Metal Contamination in the Pineapple (Ananas comosus) Cultivated tracts of Kerala, India. International Journal of Current Science Research and Review, 4(5), 415-421 